\title{
鋼、合金鐵、銑鐵等の炭素定量分析に 對し酸素氣流中の燃燒に就て
}

會 奥 村 梧 樓

丙客目次

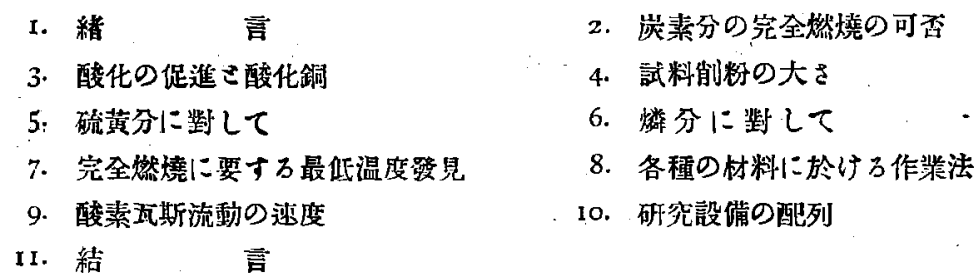

\section{1. 緒霉}

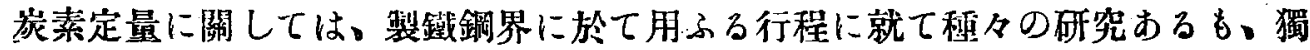
逸化學者間に於ては、以上の內容を以て分析法に尘する條項こなしれれば、之れ。 に隨つて記退すべし。

而して酸慈㴋流中に於て、鐵及び鋼類の燃燒による炭素定量ば、現今最も廣く 行はれつ〉あり。

\section{2. 炭素分の完全燃燒の可否}

既に一回燃燒定量したる、試料の炭素が完全に燃燒せるか否かる試驗するにば、

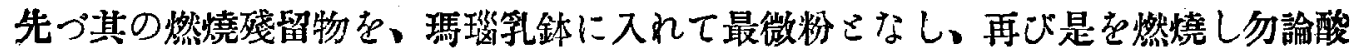
化銅在中の管を使用して之ね试驗す、而して吸收瓶に重量の差を生ぜ゙る時、完 全燃燒したるものこす。

\section{3. 酸化の促進と酸化銅}

炭素が不完全燃燒の篇めに、一部が CO こなり、炭素含有量が低〈現はる〉 此の危險は、最も炭素含有量の多きもの、即ち钱の合金例へば Ferromanganese なごのこき往々起る、之を防ぐには試料の燃燒を漸炏除々に加潐し、酸素を强度 に通過し、特に酸素の良く發生する $\mathrm{PbO}_{2}, \mathrm{~Pb}_{3} \mathrm{O}_{4}, \mathrm{Mn}_{3} \mathrm{O}_{4}, \mathrm{MnO}_{2}, \mathrm{CuO}$ の如き のを添加す。 
酸化銅管を通過したる結果、及び通過せざる結果を別に死斯容量分析方法を基 こせる正確なる結果さ、比䡥して完全燃燒したるや否を試羷したるに、酸化銅管 を通過せる方正當なりし事勿論なり。

此の時酸化銅管の温度は、約 $750^{\circ} \mathrm{C}$ を適度と認めてり、酸化用添加物を使用せ ざる時、即ち低炭素銅其の他燃燒し易き試料の第合に、酸化銅管の通過を要す。

\section{4. 試料割粉の大さ}

鎆試料の大さは成る可く同一なるべく決して厚過ざる可からす、更に泩意す心 きは餘り細微に過ぐる試料は、屡々大なる試料より異りたる結果を現し、又厚さ に過ぎるこきは燃燒の程度緩漫なら、

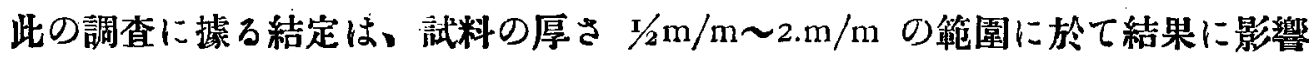
無きを認む。

\section{5. 硫黃分に龂して}

硫黄は流入酸素のO と結合して、死斯狀態をなっ $\mathrm{SO}_{2}$ 或は $\mathrm{SO}_{3}$ を形成するを以 て、是を下記の各試驗比襄を成せら。

（a）燃燒瓦斯を Sodalime に導き、增量さ結合の有無を檢す。

（b）燃燒瓦斯を加里液の四收器に導き、過酸化水素を以て酸化し、盐酸にて 酸性さなし、壗化バリカムにて硫酸バリカムこして存否を检す。

（c）前記の如く加里液に於て、检する事を得れごも、倘ほ別に燃燒死斯より $\mathrm{SO}_{2}$ 巳して、クローム硫酸溶液に吸收し、後更に加里液に導き、而して 硫酸含有量を檢す、勿諭此の際に於ては同時に炭素含有量は決定せられ to

炭素分決定にはクローム硫酸液に通過する事と、别に之を通過せざる事との 雨法を比䡴せり。

此の謂查に據万決定は、普通鎆に於て硫黄含有量は僅少なる第め、クローム硫 酸に作用したる現象は、數字的のるのに非声、但し特に硫黄含有量の多き鋼は、 $\mathrm{SO}_{2} \sim \mathrm{SO}_{4}$ として除去の設備を要す。 


\section{6. 性分に對して}

試料中の燐は、燃燒管中死斯の通過に於て如何なる状態にあるかは、加里液の

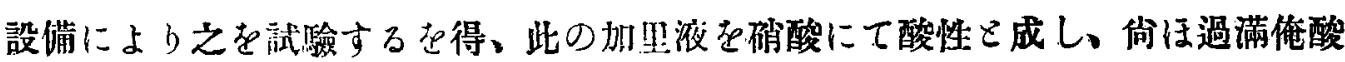
加里液にて酸化し、過剩の $\mathrm{KMnO}_{4}$ を盐酸若しくは硫酸满俺にて溶解し、倘法過 剩の壗酸あればアムモニア水にて中和し、弱酸性液に於てモりブデン酸つムモニ ニムにて、燐モリブラ゙ン酸つムモニュムとして、沈澱し檢定す。

此の調査に於て燐は炭素の結果に影響せず、敢て顧慮するの必要無き認む。

\section{\%. 完全燃燒に要する最低溫度の發見}

惯及び燃燒管の形狀は、又重大なる關係おれごも、其の温度は可成試料に適當 なる低温度にて燃燒するを可とす、完全燃燒せしむる試料に適當なる、最低温度 に於ける試料の全部の炭素を、炭酸死斯をなす事については、次の各項最す重大 の關係あり。
A. 試料の性質及び其の厚さ
B. 酸素の濕氣
C. 酸化補助用添加劑の利用及び方法
D. 燃 燒 時 間

各種の材料に對しては、其の固有の温度を必要とす例へば炏の如し。

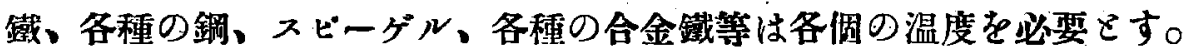
添加物の利用に際して性、特に酸素の發散するものを選み、同時に容易に流動 性を有して、Slagになるすのにて、更に一定の低温度にて作用を起するのてるを 要す、此の目的によ 万、過酸化鉛、酸化蒼捨、酸化エ゙バルト、酸化銅及び軟鋼等 を最も良しとす。

合金鐵に對しては、試料以外に欶加き鋼を前配酸化峦と共に用ふべし。 温度が低ければ從て長時間の燃燒を必要こす。

爐及び然燒管の形狀が、重大なる關係するものなる故、一方法にては可及的晠 温度にて可能なるる、他方面に於て殊に瓦斯容量分析方法に於ては、可及的短時 
間にて燃燒せしめざる可らず、然しながら重量分析方法に㨜る時は、死斯流動の

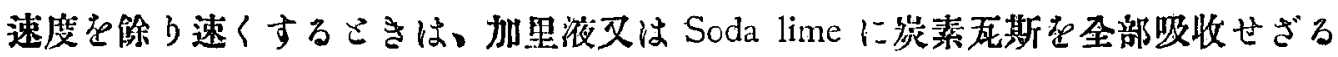
事むり、依て燃燒は餘り速加ならざるを欲す。

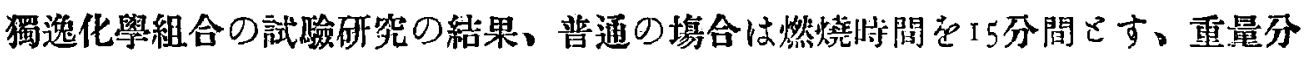
析に於ては瓭斯容量分析法より低き温度にて可能にして、燃燒時間のI5分間に比 し容量分析法の軲合は約10分間以丙にて足れり。 最低温度は添加物無きこ。、1 $1200^{\circ} \mathrm{C}$ 以下てるべし。 烝氮する酸素死斯を使用する時は、乾燥してる酸素死斯を使用してる時に比し 分析結果は高く顯るつものにして、刃濕氯は燃燒を著しく進行せしむ。

酸化補助用添加劑の作用試驗には低炭素鋼、高炭素鋼、シリコン鋼、高滿俺鋼、 高速度鋼等五種の鋼種に就き施行せり。(成績表略す)

$\mathrm{PbO}_{2}$ を以て試羷してるときに、酸化銅管が効力ありしを示せり。

炭素銅、シリコン䥤は $900^{\circ} \mathrm{C} に て$ 完全に然燒せるも、高マンガン鋼及び高速度 鍓を燃燒するには、1000 ${ }^{\circ} \mathrm{C}$ を必要とす。

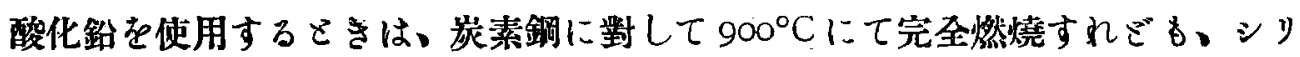
コン鎆は $900^{\circ} \mathrm{C} に て$ 悦に完全に燃燒せず、即ち酸化鉛 $\left(\mathrm{PbO}_{2}\right)$ の作用は、過酸 化鉛 $\left(\mathrm{Pb}_{3} \mathrm{O}_{4}\right)$ の作用より 除々てり。

マンガン銈及び高速度銅は $1000^{\circ} \mathrm{C}$ を必要とす。 添加劑の使用は酸化銅管の作用を習進せしむ。 lining として砂を添加する事は、價格の廉なる事の特徽を、燃燒殘留物を舟よ り容易に取り去万事を得て、舟は叉更に使用し得万效力ある故なり、然しながら

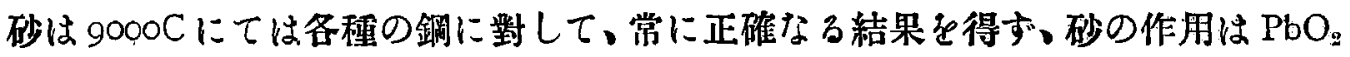
或は $\mathrm{Pb}_{3} \mathrm{O}_{4} よ り$ 䌅慢なるは勿論にして、砂の添加は酸化銅管の作用を霄進す。 酸化コバルトを添加物として、使用の塲合は酸化銅管は設備の必要を見ず。

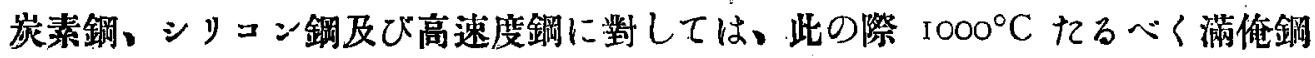
はェ100 Cたるべし。 
是等の添加剂を、以上五種の鋼に使用せる結果は、過酸化鉛が最も有効なる作 用を發揮するものなるとの浃定を得たり。

更にクローム酸鉛を充したる、銅網䓡のものを試驗せり、銅の網目は約 I cm 角 に100の目を有し、それにて卷き込みたるものなり、而して後部にクローム酸鉛 を充す。

銅線の網は下圖の如く、犷き方より突き初め、他の端には磁製の管を拆入して クローム酸鉛を充す。

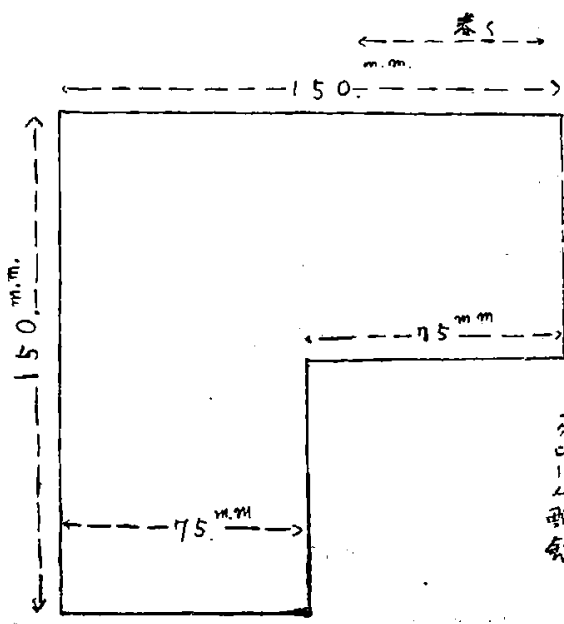

此のものはこ重の銜きを 成し、一方には $\mathrm{CuO}$ 管を 他方にはクローム硫酸設備 の二重の作用をなす。 此の試驗にて銅線網にク ローム酸鉛を充したるをの は、酸化銅管にてクローム 硫酸設備を有するものご同 一の結果を示せり、且つ前

述の四種添加物なる砂、酸化鉛、過酸化鉛、酸化ョパルト等に於けるこ同樣なる 作用を示せり。

酸化硫黄を除去するには、此の裝置が有效なるものなり。

\section{8. 各種の材料に於ける作業法}

次記の各程性分を有する銅及び鐵合金の各材料に就き、酸化劑さ温度及び燃燒 時間の調查を列記す。

銅 材:-Steel (0.05\%C, $0.35 \% \mathrm{C}, 0.90 \% \mathrm{C})$, Silicon steel, Manganese steel ( $8 \% \mathrm{Mn})$, High speed tool steel.

鐵及合铻:-Hematite pig, Thomas pig, Spiegel eisen ( $8 \% \mathrm{Mn})$, Ferro-Manganese (50\%Mn, 80\% Mu), Ferro-Silicon (12 45\%Si, 90\%Si), Ferro-Chromium, Ferro-Tunsten, Ferro-Molybdium, Ferro-Vanadium, Ferro-Aluminium. 
ヘマタイト銧、トーマス鉄、8\%Mn の Spiegel Eisen, 50\% 及び 80\%Mn の Ferromanganese は $900^{\circ} \mathrm{C} に て$ 過酸化鉛の添加を以て完全に燃燒す、此の際酸化 銅管は必要なきを認む。

グラフアイトの浃定も同樣の、試驗條件に於て行ひ得たり。

鐵類に就き添加劑を使用せすして果して完全に燃燒せざるものなるや否やを、 試羷の篇め過酸化鉛を添加したる方こ、又添加せざる方この二者に對し、施行し れるに燃燒温度 $900^{\circ} \mathrm{C}$ なるきは、添加物は必要なるも $1100^{\circ} \mathrm{C}$ 以上なるときは、 鐵は添加物の使用を要せず。

フェロシリコンの試驗には、12.\%，45\%，90.\% $\%$ Si のの尼過酸化鉛の添加に 於て、酸化銅管を通過するこせざるこに對しては、酸化銅管を通過する方完全の 結果を得、其の時の温度は $1100^{\circ} \mathrm{C}$ を要し、燃燒時間は 15 分間を要したり。

更にヌフメロンリコンに於て、過酸化鉛の添加物を稘用せすして、燃燒狀態な 試驗せしに其の結果は不充分なるを見る。

低炭素フェロクロームの妢析に於ては其の鶁料を粉粹する際に、堅きCarbicle の篇め形狀一定せず、其の篇めクローム硫酸方法を此較すれば、何れの分析室の 實驗に於ても重量法よりも低き各鋫の異りたる結果を得てり。

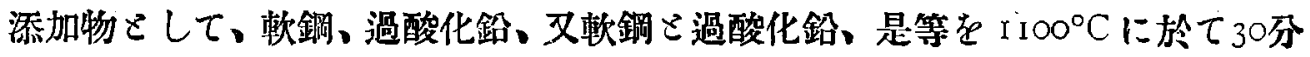
間然燒したるに、何れる正當なる結果な得たり。

次に海砂、過酸化マンガン、又海砂と過酸化マンガン是等の添加に對して温度

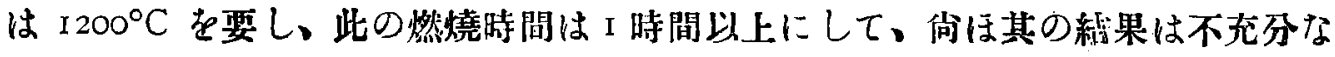
bo

高炭素フェロクロームの試羷は、燃燒試驗に先立ち硫酸クローム方法にて長時 間酸化するも結果は低く現る。

此の高炭素フェpクロームの試料に、使用の添加劑として、軟銅、過酸化鉛、 又軟鋼と過酸化鉛の混和劑を使用せる其の結果は前者より高く現れ、此の燃燒温 度は I $100^{\circ} \mathrm{C} に し て 、$ 時閒は 30 分な b、I度科量後此の際の燃燒殘留物を粉粹して 
更に過酸化鉛を添加して、燃燒してるに以上の數を筧加せざるを以て、正當なる を認む。

次に海砂、過酸化マンガン、又は海砂さ過酸化マンガンの混和劑を使用して、 温度は $\mathrm{I} 200^{\circ} \mathrm{C}$ に於て燃燒時問 $\mathrm{I}$ 時間以上を經過するる、份ほ其の結果は低きを 見る。

フェロタングスランの鹪合には、クローム硫酸法によるときは・決して正當な る結果を得ず。

酸素死斯中に於ては、フェロタンダスランは酸化劑を加へすして、900ㄷにて 完全に燃燒するものを認む。

更に過酸化鉛、或は過酸化鉛と鋼、或は鋼等の添加物を使用して、比較するに 敢て結果に厓異を現さず。

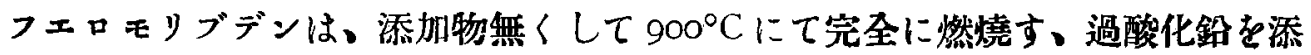
加したる㙫合も、前結果を霄加せす、文クローム硫酸法によらても同結果を得れ bo

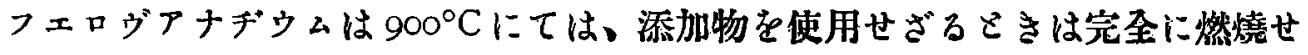
す、結果は稍々低く現はるつものなる、同温度に於て過酸化鉛を添加の鹪合は完 全に燃燒す。

フェロアルミニニームは、過酸化鉛の添加に於て完全に燃燒す、クローム硫酸 法の結果を比㜞するに、總て同栐の結果を得けり、添加劑無き時は其の結果は前 よりも低き價を示せう。

最後に酸化銅を添加して、下記種類の試料に就さ試睮せり。 0.047\%C 及 $0.36 \% \mathrm{C}$ の銅、2.\% $\mathrm{C}$ の Ferrochrom. I.15\%C, Ferro Tangsten. 3.57\%C, Ferro Molybdenum. 0.3\%C, Ferro Vauadium. 3.94\% C, Ferro Vanadium.

添加用酸化銅は常に使用の前酸素死斯中にて燒昫し、炭素を除去し置くるのなり、

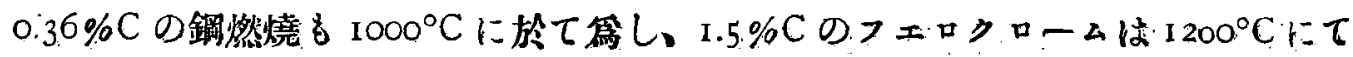

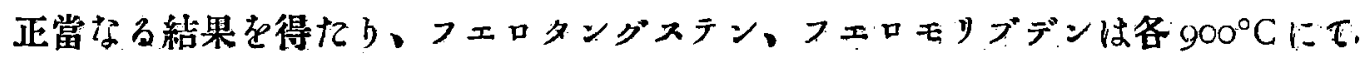


酸化銅を线入すして完全に燃燒し、正當なる數字を得たり、フェロジアナデウム は過酸化鉛の添加物と共に $900^{\circ} \mathrm{C} に て$ 完全に燃燒す。

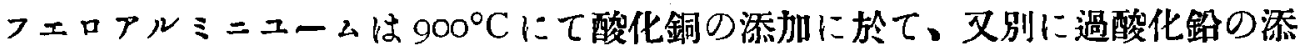
加したるものと此較したるに、同樣の結果を得たら、又炭素鎆は酸化鉛を添加 したる明さ、別に酸化銅を添加したる時さを比較したるに同樣の結果を得たる。

炭素鍽は酸素死斯声使用せすして、空氣の流入に於て完全燃燒する得。例人 ば、无の試料をこり、三倍量の酸化銅走混合し、空氣の流入に於て燃燒するこき は、15分間にて完全に燃燒することを立登するものなら。

最後に過酸化錚のブランクラストの施行は必要なることにて、過酸化鉛のみを

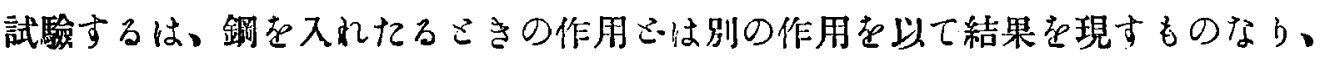
此の現象は次の如し。

過酸化鉛を造るには Dennstedt の方法により、硝酸溶液の電解にて硝酸鉛より 整造するものなる故、常に硝酸の痕跡を存す、驖鋼等の試料を入れすして、ブラ ンクテストの決定に際しては、瓦斯狀の酸化永素はソーダライムにより吸收され て、計量さるっものなる、鐵鋼等の試料を入れてブランクラストすれば、此の死 斯は硝酸鉛の分解物の一部、又は全部が Fe の作用の篇めに跮素に還元せらる、 鬼に角銅を入れてブランクテストする事は正當なりとす。

\section{9. 酸素互斯流動の速度}

酸素死斯流動の速度に關係して、尚ほ前記第 7 項の參照を要す、7 15分の燃燒 特間を決定するには、常に酸素死斯の速度に密接の關係あり、而して且つ I 分間 に3〜8 回の氣泡を決定すへし。

\section{0. 研究設備の配列}

試驗設備として獨逸國化學組合に於ては、次の裝置を推薦す。

酸素死斯ボンブの次に Pressure を調節するもの、次に加里液、硫酸、ソーダラ 亿幺（大瓶在中）、調節し得る硝子栓、空瓶、次に燃燒点（Mars 爐或は Silit 棒 を有する爐）但し温度計附、爐の次にはクローム硫酸、五酸化燐、次に約80死の 
ソーダライム及び少量の五酸化燐を入れたる、二個の吸收管、最後に硫酸を入れ たら氣泡を調節するもの。

11. 䊒 产

酸素瓦斯にて試料を燃燒する、炭素含有量の決定に對しては、濕氣する酸素を 使用せす、、クローム硫酸の設備支推萀す、燃燒管內にタローム酸鉛を入れてる銅 鋼の然き管を入るれば尚ほ可なり、酸素を發政する篇めに添加劑を用ふるとき、 酸化銅管は一層其の效力を增す。

フェロタングステン、フェロモリブデンは最を容易に燃燒し、且つ添加物を舫

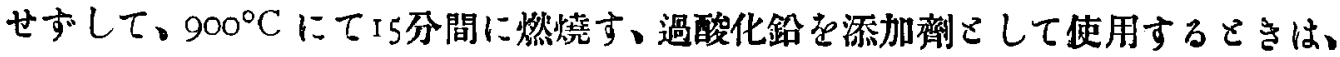
炭素鋼、シリコン鋼、銑鐵、フェロヴフナヂけム及びフエロフルミニユーム等は $900^{\circ}$ に厂5分間に完饪燃焼す。

マンガン鋼及び高速度鋼は、1 $100^{\circ} \mathrm{C} に て$ 燃燒す。

フェロシリコンは、過酸化鉛を使用し温度 $1100^{\circ} \mathrm{C}$ を要し、I5分間にて完全燃 燒すั。

フェロクロームは、各程鐵合金中最も燃燒し難く、軟鋼及び過酸化鉛の添加物

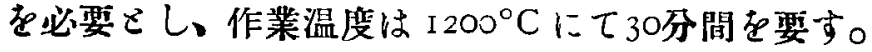

孷素鈰の時には、含有炭素の量に隹ずる故、作業温度を可燃限度よりも、それ

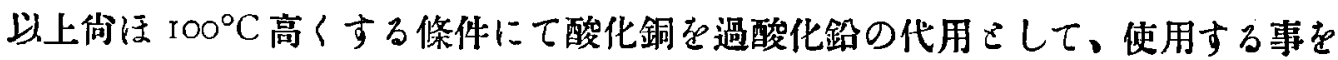
得。

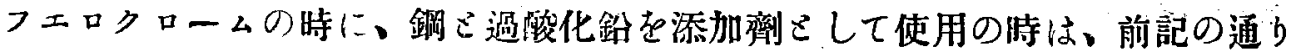

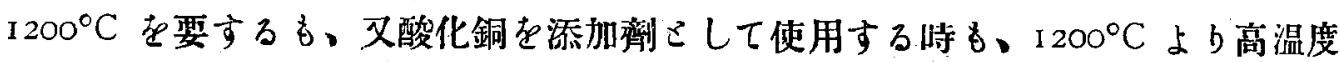
を必要させす。

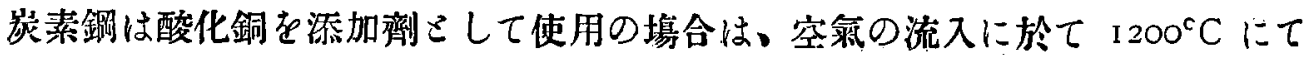
完全に燃燒す、此の際三倍量の酸化銅を使用す可きなり。一(完)ー

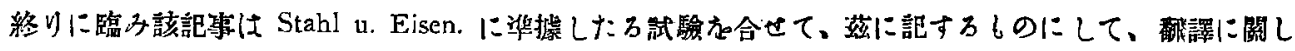
村上竹藏氏の多大なる御援助か深謝する次第なり。 